\title{
O SUBLIME EXPLICADO ÀS CRIANÇAS
}

\author{
Virginia Figueiredo ${ }^{1}$
}

$\mathrm{UFMG} / \mathrm{CNPq}^{2}$

RESUMO: Como o próprio título indica, este ensaio pretende dialogar com a recepção do sublime kantiano pela filosofia francesa contemporânea, sobretudo com Jean-François Lyotard. Dessa forma, ao invés de ressaltar as consequências inevitável ou sistematicamente morais do sublime kantiano, como fez, de um modo geral, o comentário mais tradicional da filosofia crítica de Kant, este ensaio tenta interpretar o sublime como sendo essencialmente uma experiência da arte, seguindo assim de perto aquela tradição francesa. Mas, ao mesmo tempo, tomando alguma distância, este texto quer fazer uma objeção ao fundamento exclusivamente burkiano da concepção de sublime de Lyotard. Em suma, quero defender que é possível privilegiar o tempo (aspecto central do sublime de Edmund Burke, segundo Lyotard) também na experiência do sublime kantiano.

PALAVRAS-CHAVE: Kant. Jean-François Lyotard. Estética. Sublime.

I.

Assim como afirmou Benedito Nunes sobre a Estética, disciplina filosófica que trata do Belo, que ela nasceu duas vezes: a primeira, no mundo grego, com Platão, e, a segunda, na nossa modernidade, com Kant, também podemos dizer acerca do Sublime que ele teve um duplo nascimento. No

\footnotetext{
${ }^{1}$ Virginia de Araujo Figueiredo é doutora em Filosofia pela Université des Sciences Humaines de Strasbourg (1994), com Pós-Doutorado em Boston College (2003) e na Université Marc Bloch de Strasbourg (2010). Desde 1996, é professora do Departamento de Filosofia da Universidade Federal de Minas Gerais, e trabalha principalmente na área de Estética. Entre 2003 e 2008, foi editora da Revista Kriterion. Publicou ensaios em livros como Belo, Sublime e Kant (Ed. UFMG, 1998); Mimesis e expressão (Ed. UFMG, 2001); nas Atas do IX Kant Congresso Internacional Kant und die Berliner Aufklärung e do X Congresso Internacional Kant Recht und Frieden in der Philosophie Kants; Os filósofos e a arte (Ed. Rocco, 2010). Também escreve em revistas como Kriterion, O que nos faz pensar? e Artefilosofia.

${ }^{2}$ Este trabalho resulta de uma pesquisa que contou com o apoio de uma bolsa de Pós-Doutorado no Exterior (PDE), concedida pelo CNPq, entre os anos 2009-2010.
} 
entanto, somos obrigados a fazer alguns acertos e retificações nessa gênese que, tratando-se do Sublime, é sempre mais complicada do que a do Belo. Por exemplo, ao contrário do belo que, com Platão, já nasceu grego e, portanto, automaticamente filosófico, o sublime nasceu latino e, por conseguinte, retórico ${ }^{3}$; se é inegável a ligação do belo com o prazer, no caso do sublime, temos de enfrentar um sentimento contraditório que lida, ao mesmo tempo, com o prazer e o desprazer; se o belo aponta para um sentimento reconfortante de acordo entre o homem e a natureza, o sublime mostra uma natureza inimiga do homem; se o belo é um sentimento de prazer estético por excelência, o sublime é um sentimento que, por seu vínculo com a moralidade, exige mais uma Antiestética do que, propriamente, uma Estética. Mas, não nos precipitemos tanto, e tentemos contar uma história, como nos aconselhava Aristóteles, com início, meio e fim.

A primeira notícia que se tem do sublime é muito antiga: ela data, mais ou menos, do III século da Era Cristã. É um tratado "Do sublime" (Peri Hupsous), escrito por um certo Longino, que assinava também Dionísio, o qual era um retórico. $\mathrm{Na}$ época, era o artista que era visado e, por isso, escreviamse Poéticas e Retóricas, e não Estéticas. Longino estava exclusivamente preocupado em ensinar aos oradores "[...] os meios de persuadir e de comover seu auditório. A didática da arte oratória era, então, tradicional desde Aristóteles, Cícero e Quintiliano, e tinha sido essencial à instituição republicana: era preciso saber falar diante das assembléias e dos tribunais." Apenas na modernidade, essa didática destinada ao retórico (ou ao político) será substituída pela Estética, que é a análise dos sentimentos do espectador. Como indica Lyotard, a pergunta não era mais “[...] como fazer a arte? Mas: o que é experimentar a arte?" 5 Talvez tenha o sublime participado dessa mudança; de qualquer modo, é essa a história do seu primeiro nascimento.

\footnotetext{
${ }^{3}$ Excetuando-se a Filosofia francesa contemporânea, que recebeu o sublime de braços abertos, talvez o estatuto filosófico do sublime continue, ainda hoje, em questão para outras tradições. Prova disso é que a maioria dos intérpretes de Kant, sobretudo os da "[...] tradição anglo-americana e germânica da filosofia no século vinte", como indicou Paul Crowther (na primeira página do seu livro The kantian sublime, Oxford: Oxford University Press, 1989), negligenciaram ou pouco se interessaram pelo sublime. Ao contrário, essa importante recepção da Estética kantiana voltou sua atenção, de maneira quase exclusiva, para o belo. O rol dos autores listados por Crowther é grande e inclui, entre outros, nomes como Paul Guyer, Donald Crawford, Francis Coleman, Eva Schaper, Theodore Uehling, Salim Kemal e Mary McCloskey.

${ }^{4}$ LYOTARD, J.F. Le sublime, à présent. Po®sie, no 34, Paris, $3^{\circ}$ trimestre, 1985, p.100.

${ }^{5}$ Idem, p. 103.
} 
Quanto ao seu segundo nascimento, no final do século XVII, início do século XVIII, na França Clássica, podemos considerar que ele foi precoce. Renasceu ainda como uma noção mais ligada à crítica literária e à retórica do que propriamente à filosofia. Esse parto prematuro consistiu numa surpreendente tradução, feita por um escritor e crítico de arte francês, o clássico e conservador Nicolas Boileau, dito Boileau-Despréaux. Em 1674, ele publicou, junto com sua Arte Poética, a tradução do Tratado de Longino e, com isso, muito provavelmente, provocou o reaparecimento do sublime na cena da reflexão sobre a arte, instalando assim o que viria a ser a primeira "moda" (segundo a expressão de Jean-Luc Nancy ${ }^{6}$, referindo-se à sua retomada pelo pensamento francês contemporâneo) moderna do sublime.

Transformando a história desse conceito em geografia, vemos o Sublime sair da França, ser exportado como um produto do Classicismo racionalista de Boileau, e, após a travessia do Canal da Mancha e do Mar da Irlanda, chegar a Dublin, já totalmente transfigurado por uma Estética sensualista e empirista. Em 1757, o irlandês Edmund Burke, com apenas 28 anos, publica sua famosa Philosophical Enquiry into the origin of our ideas of the sublime and beautiful. Como era de se prever, todas essas aventuras redundaram num fortalecimento da questão do sublime, que, retornando para o continente (europeu e "metafísico", porém, em vias de produzir a sua "Crítica"), só fez crescer e se solidificar, especialmente quando chegou à cidade de Königsberg, onde vivia um filósofo ultrassóbrio chamado Emmanuel Kant. Após haver publicado suas duas primeiras Críticas, a da Razaão Pura (sobre o conhecimento) e a da Raz̨ão Prática (sobre a ação moral), em 1790, Kant publica a Crítica da Faculdade do Juízo (que passo a chamar aqui de " $3^{a}$ Crítica") $)^{7}$. Essa $3^{a}$ Crítica é composta de duas partes principais: a primeira, sobre os juízos estéticos, e a segunda, sobre os juízos teleológicos. A primeira parte, dedicada aos juízos estéticos, foi, por sua vez, dividida em duas Analíticas: a do Belo e a do Sublime.

Depois de passar rapidamente pela história e geografia do Sublime, gostaria de abordar a sua mudança de caráter. Quando o sublime empreende a sua venturosa viagem da Crítica Literária para a Filosofia, ele sofre uma metamorfose, já anunciada por Longino, que consiste na passagem de um estilo

\footnotetext{
${ }_{6}$ NANCY, J. L. L'offrande sublime. In: DEGUY, Michel; NANCY, J. L. (Org.). Du Sublime Paris: Belin, 1988.

${ }^{7}$ KANT, I. Kritike der Urteilskraft (AA, 05); Crítica da Faculdade do Juizo. Trad. Valério Rohden e Antonio Marques. Rio de Janeiro: Forense Universitária, 1993.
} 
sublime, que designa, em geral um tom elevado e uma linguagem rebuscada, a um sublime de pensamento, cuja expressão filosófica já é, ao contrário, a simplicidade ${ }^{8}$. Ou, nas palavras de Lyotard: "[...] o sublime deixa de ser uma questão de elevação para se tornar questão de intensificação". ${ }^{9}$ Kant foi o primeiro a zombar do tom altaneiro e presunçoso que assumiam os assuntos da metafísica e, por isso, tentou fundar sua filosofia transcendental sobre um princípio simples - que não se opõe ao difícil, mas ao pedante e ao pomposo -, e que é, afinal, o da crítica. Portanto, ele tinha tudo para acatar aquela metamorfose do sublime, e acolhê-lo em sua "Estética".

Contudo, incapaz de prever que o sublime tinha entrado para a filosofia de modo definitivo, para nunca mais sair dela, Kant, mau profeta, pareceu desprezá-lo, e até dele desdenhar, chegando a dizer que a "Analítica do Sublime" não passava de um "Apêndice" à "Analítica do Belo"10. Assim, foi à sua revelia e, de certo modo, contra Kant, que a Filosofia Francesa do século XX resgatou o Sublime e restaurou a sua moda, tornando ironicamente aquele "Apêndice" uma de suas peças-chave. Foi nessa "Analítica do Sublime" onde boa parte da reflexão francesa contemporânea" sobre a arte encontrou suas sementes mais prolíferas. Esses comentadores franceses são unânimes em afirmar que é nela, onde se desenrola uma possível Teoria kantiana da Arte, se for legítimo afirmar que Kant tenha tido sequer a intenção de escrever uma. Sabe-se, ao contrário, que o grande (talvez único) problema kantiano seja o da natureza. A arte parecia apenas um advérbio, um modo, elemento de uma analogia que se impuseram ao filósofo transcendental obcecado em dar conta da unidade da experiência. Foi por amor ao sistema que Kant teve de reconhecer e não pôde ignorar, paralelamente ao olhar científico e mecânico, a possibilidade de outro (Duplo) olhar, uma outra perspectiva (isso é muito

${ }^{8}$ Cf. interpretação do sublime kantiano proposta por ESCOUBAS, E. Kant ou la simplicité du sublime. In: Du Sublime, Paris: Ed. Belin, 1988.

9 Cf. LYOTARD, J. F., op.cit., p.104. Na verdade, Lyotard não está fazendo uma referência genérica ao sublime, mas aludindo especificamente ao sublime burkiano: "Le sublime n'est plus pour Burke affaire d'élévation (qui est la catégorie par laquelle Aristote distinguait la tragédie), il est affaire d'intensification."

${ }^{10}$ KANT, I. (AA, 05: 78), CFJ, p. 92: "Disso vemos que o conceito de sublime da natureza não é de longe tão importante e rico em conseqüências como o do belo [...] e a sua teoria um simples apêndice etc."

${ }^{11}$ Apesar de este texto estabelecer um diálogo privilegiado com Jean-François Lyotard, talvez seja o momento de lembrar a lista (oposta à da nota 1) de autores franceses que se dedicaram ao sublime, tratando-o como um conceito filosófico. A começar por Jacques Derrida, o rol, mesmo incompleto, tem de incluir os nomes de Jean-Luc Nancy, Philippe Lacoue-Labarthe, Eliane Escoubas, Jacob Rogozinski, Jacques Rancière. 
importante, porque ela não pretende anular ou aniquilar o olhar mecânico, mas somente acrescentar-se, somar-se a ele), voltados para a (mesma) natureza.

\section{II.}

Por menos que o sisudo Kant tivesse apreciado a Investigação filosófica sobre a origem de nossas idéias do sublime e do belo ${ }^{12}$ do jovem e genial irlandês Edmund Burke, tendo-a mesmo considerado como empírica e fisiológica ${ }^{13}$ (características negativas ou viciosas, para Kant), foi ela que, atualizando um elogio, já contido no Tratado de Longino, à poesia em detrimento das outras artes, deu a Kant um dos motivos principais da "Analítica do sublime": o de uma passagem entre o estético e o ético, ou, na sua própria terminologia, uma passagem do sensível ao moral. Vejamos, em primeiro lugar, como esse elogio às artes da palavra acontece.

$\mathrm{Na}$ última parte, numa espécie de (inevitável) Apêndice de sua Investigação, Burke desenvolveu uma verdadeira teoria das palavras. Ali, ele dizia que a eloquência e a poesia podiam provocar impressões não somente mais vivas e profundas do que por quaisquer outras artes, como também mais fortes, em alguns casos, do que a própria natureza. As palavras, continuava ele, devem seu grande poder ao som, à imagem ou ainda à afecção produzida na alma do auditório. No caso da primeira afecção, pelo som, "as palavras podem afetar sem produzir imagens" ${ }^{14}$. Essa era então, uma das virtudes da poesia, que nos permite não somente opor esse tipo de arte à pintura, por exemplo, caracterizada como arte de imitação, como dignificá-la e colocá-la num nível superior às demais artes. Aliás, a discussão sobre a hierarquia das artes era muito frequente nessa época.

Depois de haver oposto a poesia às artes de imitação e classificá-la numa posição de superioridade, Burke acrescenta ainda que sua potência de comover se deve à simpatia. Por conseguinte, será através da simpatia que as artes da palavra conseguirão nos liberar, de um lado, do constrangimento da realidade e da imitação, e, de outro lado, da nossa individualidade. Primeiramente, porque

\footnotetext{
${ }_{12}$ BURKE, E., Uma investigação filosófica sobre a origem das nossas idéias do sublime e do belo. Trad. Enid Abreu Dobránszky. Campinas, SP: Papirus Editora da Universidade de Campinas, 1993.

${ }^{13}$ KANT, I. (AA, 05: 128), CFJ, p. 123.

${ }^{14}$ Ibidem, p. 173-177. Trata-se de uma Seção inteira, V: "Exemplos de que as palavras podem causar efeito sem que suscitem imagens." 
as palavras podem produzir "combinações impossíveis"15 de se apresentarem na realidade; em seguida, porque "partilhamos extraordinariamente das paixões dos nossos semelhantes" ${ }^{16}$. Tomemos o desvio do Apêndice para alcançar a definição do sublime em Burke.

Muito já se falou da interpretação psicológica que Burke nos deixou do sublime. Efetivamente, ele buscou esse sentimento em emoções como o medo, o terror, a privação e, num sentido mais geral, no prazer e na dor, que são sentimentos comumente atribuídos à subjetividade. Mas, se há algum sujeito, alguma subjetividade no sublime, ela está à beira da desagregação, do dilaceramento, pois, a paixão que define o Sublime está entre aquelas mais fortes: a paixão de conservar a vida. Essa é uma emoção que só sentimos quando estamos ameaçados de perder o que nos é mais precioso, i.e., a vida. O medo mais extremo é sempre medo de morrer. Se o desdobramos empiricamente, ele se torna medo das trevas, da solidão, das grandes extensões, das alturas excessivas - todos esses medos são enumerados e examinados no livro de Burke. Poderíamos resumir a fórmula geral do sublime da seguinte maneira: uma relação de ameaça diante da grandeza do que quer que seja, pois nela pressentimos uma potência capaz de nos destruir. Que o Sublime, enquanto sentimento diante da grandeza, se distinga do Belo, concordam ambos, Burke e Kant e, aliás, toda Estética do século XVIII. Em uma de suas principais definições (do ponto de vista matemático), o Sublime kantiano é apresentado como "o que é absolutamente grande" 17 , magnitudo, grandeza que precede a própria quantitas, quantidade (categoria do entendimento).

Além dessa grandeza, cujo estatuto é bastante complexo, justamente porque não é conceitual, a outra noção que importa na definição do Sublime é a de um prazer contraditório ou negativo, dependente da dor e de seu distanciamento. Burke salienta: “[...] delight” (deleite): "Empregarei a palavra deleite para indicar a sensação que acompanha a eliminação da dor ou do perigo."18 E mais: "[...] essa dor, esse perigo devem agir a certa distância, com algumas modificações" "19. Há uma idêntica contrariedade apontada por

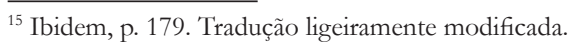

${ }^{16}$ Ibidem, p. 178.

${ }^{17}$ KANT, I. (AA, 05: 80), CFJ, p. 93.

${ }^{18}$ BURKE, E., op.cit., p. 46.

${ }^{19}$ Idem. Retomo aqui os termos da tradução para o francês (Recherche philosophique sur l'origine de nos idées $d u$ sublime et $d u$ beau. Trad. E. Lagentie de Lavaisse, Paris: Librarie Philosophique J. Vrin, 1973, p. 70), 
Lyotard no sublime kantiano, no qual "o prazer está limitado pelo desprazer"20. Também em Kant, repete-se a "distância” de Burke, e, numa famosa e muito citada passagem, ele descreve a cena do sublime como o espetáculo de uma natureza desregrada, diante do qual nos encontremos (sujeitos, espectadores) "em segurança".

Cito as duas passagens, primeiramente, Burke e, em seguida, Kant, de forma que o próprio leitor constate o quanto dialogavam os dois filósofos:

Tudo o que seja de algum modo capaz de incitar as idéias de dor e de perigo, isto é, tudo que seja de alguma maneira terrível ou relacionado a objetos terríveis ou atue de um modo análogo ao terror constitui uma fonte do sublime, isto é, produz a mais forte emoção de que o espírito é capaz. [Digo a mais forte emoção, porque estou convencido de que as idéias de dor são muito mais poderosas do que aquelas que provêm do prazer. Sem dúvida alguma, os tormentos que nos podem ser infligidos são muito maiores, quanto ao seu efeito sobre o corpo e o espírito, do que quaisquer prazeres que os hedonistas mais consumados poderiam sugerir, ou do que a imaginação mais vívida e o corpo mais sadio e requintadamente sensível poderiam gozar. [...] Contudo, não obstante o efeito da dor seja muito mais forte do que o do prazer, ela geralmente causa uma impressão muito menor do que a idéia de morte, dado que dificilmente a esta se prefere, até mesmo em lugar das dores mais extremas; ademais, o que geralmente torna a própria dor, se me é lícito dizê-lo, mais dolorosa é ser considerada a emissária dessa rainha dos terrores.] Quando o perigo ou a dor se apresentam como uma ameaça decididamente iminente, não podem proporcionar nenhum deleite e são meramente terríveis; mas quando são menos prováveis e de certo modo atenuadas, podem ser - e são - deliciosas, como nossa experiência diária nos mostra. ${ }^{21}$

Kant:

Rochedos audazes sobressaindo-se por assim dizer ameaçadores, nuvens carregadas acumulando-se no céu, avançando com relâmpagos e estampidos, vulcões em sua inteira força destruidora, furacões com a devastação deixada para trás, o ilimitado oceano revolto, uma alta quedad'água de um rio poderoso etc. tornam a nossa capacidade de resistência de uma pequenez insignificante em comparação com o seu poder. Mas o seu espetáculo só se torna tanto mais atraente quanto mais terrível ele é,

a qual nos fornece: "Lorsque le danger et la douleur pressent de trop près, ils ne peuvent donner aucun délice; ils sont simplement terribles: mais à certaines distances, et avec certaines modifications [grifo meu] ces affections pewvent devenir et deviennent réellement délicieuses."]

${ }^{20}$ LYOTARD, J.F. Liçoes sobre a Analítica do sublime. Trad. Constança Marcondes César e Lucy R. Moreira César, Campinas, SP : Papirus, 1993, p. 94.

${ }^{21}$ BURKE, E., op.cit. p. 48. 
contanto que, somente, nos encontremos em segurança; e de bom grado denominamos estes objetos sublimes, porque eles elevam a fortaleza da alma acima de seu nível médio e permitem descobrir em nós uma faculdade de resistência de espécie totalmente diversa, a qual nos encoraja a medir-nos com a aparente onipotência da natureza. ${ }^{22}$

A meu ver, essa proximidade com o terrível é uma parte delicada e importante do problema do sublime. Daí a necessidade de estabelecer, como destaca Burke, "[...] uma certa distância" ou uma certa "segurançca", na qual Kant acomoda o "seu" espectador. Contudo, o que estariam querendo dizer, tanto a "distância do perigo", em Burke, quanto à posição de "segurança" do espectador kantiano? Será que, diante do espetáculo trágico da vida ou da natureza enfurecida, eles nos estariam propondo um pensamento expresso, mais ou menos com estas palavras? "Ufa! Ainda bem que isso não está acontecendo comigo e sim com outro...”? Ou, como acontece frequentemente, quando acordamos de um pesadelo e suspiramos aliviados: "Ah! Era só um sonho!"?

No meu modo de interpretar essas passagens, essa solução é inadmissível. Ela consistiria em alijar a arte mais uma vez e, o que é pior, platonicamente, para o lugar da falsidade ou da potência que quer ludibriar e enganar. Isso sem contar o fato de que um comentário como aquele revelaria uma moral perversamente egoísta do espectador (tanto kantiano quanto burkiano). Ora, especialmente no caso de Kant, não acabamos de afirmar que o sublime propõe uma passagem do sensível ao moral? Como conciliar então essa vocação moral do sublime com um espectador egoísta e perverso, que só vê a si mesmo e só quer salvar a própria pele?

Não entenderemos essas passagens, que reconheço serem bastante ambíguas, sem apelar para um questionamento das relações que jogam entre si arte e realidade. Com esse fim, farei mais um desvio, para pedir socorro a Schiller, esse filósofo que leu tão atentamente a $3^{a}$ Crítica e que, em matéria de arte, talvez tenha atingido um nível de reflexão insuspeitado por Kant. Fiel às distinções kantianas, Schiller estabelece que um passo em direção à Cultura só pode ser dado, uma vez que nos tornemos capazes de indiferença para com a realidade e que, na mesma medida, cresça o nosso interesse pela aparência. ${ }^{23}$ É

\footnotetext{
${ }^{22}$ KANT, I. (AA, 05: 104), CFJ, p. 107.

${ }^{23}$ Cf. Carta XXVI de $A$ educação estética do homem numa série de cartas. Trad. de Roberto Schwarz e Márcio Suzuki, São Paulo: Iluminuras, 1990, p.134. Para levar à frente seu argumento, Schiller precisa diferenciar "aparência estética" de "aparência lógica", a fim de estabelecer que a apreciação da primeira 
preciso, portanto, nesse primeiro momento da distinção entre arte e realidade, levar em conta que a aparência estética não é o mesmo que a aparência lógica (real ou verdadeira), nem pretende com ela se confundir e, muito menos, substituí-la. Dou um exemplo, para facilitar um pouco essa delicada discussão.

Trata-se do famoso exemplo que vem desde Platão, do pintor que pintou uvas tão idênticas às da parreira que um pássaro, confundido, veio bicálas. Esse foi um dos primeiros sentidos, negativo, muito negativo, que Platão deu à aparência estética, e que o levou à condenação da arte. Essa atividade que produz "[...] objetos aparentes sem qualquer realidade"24 e que, no entanto, pretende confundir-se com a realidade, ou melhor, substituí-la: a uva de verdade pela uva de mentira. Arte que visava ludibriar e enganar o ingênuo espectador grego, carente dos critérios para diferenciar a arte (pura aparência, superfície, reflexo das coisas no espelho) da realidade (essência profunda e verdadeira das coisas); contra ela, cuja intenção principal era enganar, Platão investiu toda sua força argumentativa. Todavia, não foi apenas Platão: nós deparamos com um argumento semelhante, a cada vez que um filósofo (todo e qualquer) da arte se dispõe a elucidar a essência da arte. Até o próprio Kant, que sempre defendeu a dignidade do fenômeno, muitas vezes repetiu, na $3^{\text {a } C r i ́ t i c a, ~ q u e ~ n o s s o s ~ j u i ́ z o s ~ p a r a ~}$ avaliar tanto o Belo quanto o Sublime, os chamados "juízos reflexionantes estéticos", eram "[...] indiferentes à existência do objeto". ${ }^{25}$ E o que quer dizer isso, senão aquele mesmo pressuposto inicial da diferença entre o estético e o lógico, em outras palavras, entre a arte e a realidade?

Mas, se o ponto de partida de todo artista sincero e autêntico é essa liberação da realidade, que contém inegavelmente um aspecto negativo, i.e., de recusa, renúncia a ser realidade, este não deve ser, de modo algum, o ponto de chegada. O movimento de liberação ou emancipação da arte com relação à realidade não para na renúncia; caso contrário continuaríamos a aprisionar o pensamento sobre a arte dentro do par metafísico e platônico que opôs tão tradicional e acirradamente a essência à aparência. Há uma dinâmica quase paradoxal entre arte e realidade (ou arte e natureza), cujo movimento tento descrever a seguir.

(aparência estética) não prejudica em nada a verdade ou a realidade das coisas, na medida em que não pretende substituir as coisas reais. Não pretende matar a fome de um homem com uma maçã pintada. ${ }^{24}$ Cf. paradigma do espelho, in: PLATÃO, República X, 596e.

${ }^{25}$ KANT, I. (AA, 05: 5), CFJ, p. 49, grifo meu. 
Se, no primeiro momento, negativo, a arte tem que se destacar da natureza (ou da realidade efetiva), assumir profundamente sua essência artificial e assumir-se, segundo a terminologia kantiano-schilleriana, como aparência estética e não lógica; no segundo momento (e é por exigência da exposição analítica que somos obrigados a distinguir tais momentos que são, na verdade, um só e mesmo momento), positivo, a arte tem que se apresentar segundo sua verdade e realidade, a partir de conexões lógicas, todavia, de certo modo, já autônomas com relação à realidade tal como ela se nos apresenta. Quero dizer, a arte, ao assumir sua essência de ficção, não precisa se apoiar naquilo (ou restringir-se a imitar aquilo) que ocorreu. Nesse momento, a arte se torna liberdade positiva e emancipadora, uma vez que não precisa justificar o real, histórico, o status quo.

Como enfatiza Schiller, insistindo sobre o caráter rebelde que resiste em toda arte digna desse nome, que ela pode "[...] unificar com liberdade ilimitada o que a natureza separou, tão logo lhe seja concebível esta união, e pode separar o que a natureza havia unificado, tão logo consiga realizar a separação em seu entendimento." ${ }^{26}$ É somente nesse sentido que nossa experiência de mundo é ampliada, que podemos experimentar algo além da natureza e da realidade. Experiência essa que chamei um dia de "espaço e tempo absolutos" ${ }^{27}$, mas que hoje gostaria de rebatizá-la de "mundo da liberdade". Façamos valer radicalmente a doutrina da Poética aristotélica: "não é ofício do poeta narrar o que aconteceu; é, sim, o de representar o que poderia acontecer [...] diferem o historiador e o poeta [...] em que diz um as coisas que sucederam, e o outro as que poderiam suceder. Por isso a poesia é algo de mais filosófico e mais sério do que a história." ${ }^{28}$

${ }^{27}$ Refiro-me aqui ao título da minha tese de Doutorado "O sublime enquanto experiência do tempo e do espaço absolutos". Concedo quanto à impossibilidade de, mantendo a rigorosa terminologia de Kant, transformar a sua própria Estética (a que está presente na $3^{\text {a }}$ Crítica) numa Estética Transcendental, como pretendi lá se vão agora vinte anos. E não tenho receio algum de dizer que hoje não encontro mais interesse em defender essa tese ambivalente, na medida em que, fiel aos termos de Kant, pretendia um pouco ingenuamente subvertê-los. Entretanto, se cedo quanto à terminologia, em contrapartida, não estou disposta a abrir mão, nenhum milímetro sequer, do que acreditei (já acreditava antes, talvez, sem conseguir formular com muita clareza) estar contido sob aqueles termos. Talvez tenha de chamar o sublime de "verdade da obra de arte".

${ }^{28}$ ARISTÓTELES. A Poética (1451 a 36). Trad. Eudoro de Souza. , Rio de Janeiro: Abril Cultural, 1979, p. 249 (Col. Os pensadores).
} 
Antes de voltarmos a Kant, permitam-me a longa citação de uma passagem daquela mesma Carta XXVI, de Schiller, onde se encontra, a meu ver, uma irretocável reflexão sobre essa dialética entre arte e natureza:

\begin{abstract}
A aparência é estética somente quando é sincera (renunciando expressamente a qualquer pretensão à realidade) e autônoma (despojandose do apoio da realidade). Tão logo seja falsa e simule a realidade, tão logo seja impura e careça da realidade para seu efeito, ela torna-se nada mais que um baixo instrumento para fins materiais e nada pode provar quanto à liberdade do espírito. Não é necessário, de resto, que seja sem realidade o objeto onde encontramos a bela aparência; basta que o nosso juízo não se atenha a esta realidade, pois enquanto ele se atém não é estético. Uma beleza feminina viva aprazer-nos-á num grau igual ou maior do que uma igualmente bela apenas pintada; na medida, contudo, em que nos apraz mais do que esta, não apraz mais como aparência autônoma, já não apraz como sentimento puramente estético, pois a este o que é vivo pode aprazer apenas como aparência e o real apenas como Idéia; é claro, porém, que se exige um grau incomparavelmente mais alto de bela cultura para sentir apenas a aparência pura no que é ele mesmo vivo do que para sentir falta de vida na aparência." ${ }^{29}$
\end{abstract}

Com a ajuda de Aristóteles e Schiller, retiremos da cena da natureza tanto o espectador burkiano quanto o kantiano. E tentemos ler a "distância" de Burke e a "segurança" de Kant dentro de outra cena: a da "obra de arte". Desloquemos esse espectador para o museu, ou melhor, para a plateia de um teatro, e analisemos seus sentimentos. Ao contrário do egoísta perverso ("Ufa! Ainda bem que a catástrofe natural está afetando a outro e não a mim...”), colocado diante da realidade (ou verdade) da arte, o espectador é impelido a experimentar a dor que afeta o outro (continuando no exemplo do teatro: o sofrimento de Édipo), como se fosse ele mesmo. O espectador sofre como se fosse Édipo, já que, como vimos acima, “[...] partilhamos extraordinariamente das paixões dos nossos semelhantes". Além disso, segundo Lacan, não temos acesso direto ao real ${ }^{30}$. É a ficção que nos garante esse acesso. A intensidade

\footnotetext{
${ }^{29}$ SCHILLER, op.cit., p. 136.

${ }^{30}$ LACAN, O Seminário - livro VII, A Ética da psicanálise. Rio de Janeiro: Zahar, 1988, p. 22. Estudando o Theory of fictions de J. Bentham, Lacan afirma que foi ele quem percebeu, inicialmente, que o fictício está longe de ser o enganador. Bentham queria reduzir toda a verdade ao seu referente empírico e percebeu que, sem o discurso, a própria realidade perderia consistência. Finalmente, Bentham concluiu que as entidades ficcionais seriam "essa sorte de objetos que, em toda linguagem, por razões de discurso, devem ser ditas existentes" (Cf. BENTHAM. Théorie des Fictions, p. 58). Devo essa referência e nota, integralmente, a Bruno Almeida Guimarães, a quem aproveito para agradecer aqui.
} 
do sentimento do espectador provém da realidade (ou verdade) que ele atribui à arte; nesse passo, qualquer suspeita sobre a falsidade ou irrealidade da arte seria repugnante e imediatamente transformada em má intenção do artista. Para que o espectador mobilize toda sua capacidade "simpática" e se lance em direção ao outro, é preciso que a arte, como diz Kant, pareça natureza, realidade espontânea, e como diria talvez um grego, é preciso que o espectador seja persuadido com eficiência, i.e., através da verossimilhança.

Antes de sucumbir completamente na dor ou sofrimento do outro, no desespero de Édipo, ao descobrir sua verdadeira história, o espectador reconhece a sua (ou da arte?) "distância", e é nesse momento, com a possibilidade da reflexão e da crítica que, no meu entender, se dá o "sentimento de prazer". Estará sendo esclarecido aqui um dos difíceis enigmas da $3^{a}$ Crítica? Aquele que Kant denominou sentimento da reflexão e que concerne tanto ao belo quanto o sublime? Porém, deixemos de lado o belo e concentremo-nos no Sublime que produz imediatamente uma sensação de desprazer (ou dor). Continuemos a acompanhar o nosso espectador que, se sai do teatro, como na manhã seguinte de uma noite cheia de pesadelos, constatando, aliviado, ${ }^{31}$ que a cena se passou em outro tempo e espaço, se é que se passou "historicamente" (e isso, como vimos na questão do desinteresse, tratando-se de arte, pouco importa), e que se tratava de uma "representação" (de uma peça de teatro), ou de um sonho (no caso da manhã seguinte), isso não significa que a experiência não tenha ocorrido, e muito menos que ele tenha se poupado de atravessá-la.

O sentimento de alívio ("da efusão da força vital" 32 , nas palavras de Kant) depende justa e precisamente da travessia da experiência ("da momentânea inibição das forças vitais" 33 ). Se permanecêssemos indiferentes aos sofrimentos de Édipo e sua dor não nos contagiasse, então, certamente não experimentaríamos o sentimento de alívio (alívio de quê, se não tivesse havido dor e sofrimento?). Mas, nunca se deve esquecer que os sentimentos

\footnotetext{
31 O "alívio" é um termo frequentemente utilizado para definir o sublime. Cf. KANT, I. (AA, 05: 43), CFJ, p. 72: “Comoção, uma sensação cuja amenidade é produzida somente através de inibição momentânea e subseqüente efusão mais forte da força vital, não pertence absolutamente à beleza. Sublimidade (com a qual o sentimento de comoção está ligado) etc.” Não corresponderá essa dinâmica da inibição das forças vitais (terror e piedade) seguida de alívio ("subseqüente efusão") à "purificação" que estava em jogo na catarse aristotélica? Como veremos mais adiante, trata-se de um termo central na Estética de Burke.

${ }^{32}$ Cf. KANT, I. (AA, 05: 75), CFJ, p. 90.

${ }^{33}$ Ibidem.
} 
de prazer e dor são estéticos, e, para Kant, isso quer dizer que eles são reflexivos e, portanto, não determinantes, i.e., eles não precisam desencadear, nem muito menos determinar uma ação no mundo, como ocorreria se uma pessoa se encontrasse no meio de uma tempestade, ou de um furacão na realidade efetiva, que é terrível. $\mathrm{Na}$ urgência da ação, não se experimenta, é claro, sublimidade alguma! A realidade efetiva exige uma ação, no caso, sem demora ${ }^{34}$ : seja a fuga para preservar a própria vida, seja a tentativa de socorro solidário para salvar a vida alheia, dos que estão correndo risco de perdê-la! Uma coisa é o perigo (terror) no domínio da ação prática, e outra, a experiência com a arte, o pensamento, e até com a própria linguagem, como indicou o poeta Hölderlin, capaz de propiciar uma intensa experiência (sublime): de "perigo e salvação", nas palavras do poeta:

Mas onde há perigo, cresce

Também o que salva. ${ }^{35}$

$\mathrm{Na}$ "Analítica do Sublime", i.e., no "Sublime Filosófico"36 (e não mais "Retórico"), está enfatizado que ele é um sentimento de dor e prazer ao mesmo tempo ${ }^{37}$. Afirmar que é a própria representação que oferece essa passagem da cena do sofrimento à sua salvação (enquanto representação) pressupõe a nossa capacidade de viver a dor do outro, ocuparmos o seu lugar, de nos transportarmos para fora de nós, nessa generosidade essencial que marca todo pensamento (mas também toda obra de arte) autêntico(a) e genuíno(a).

\footnotetext{
${ }^{34}$ Utilizo aqui intencionalmente a expressão "sem demora", a fim de ressaltar a oposição dessa atitude (de um agente no mundo diante do terrível) àquela outra, reflexiva, do espectador diante da "representação", diante da qual ele se demora - weilen (KANT, I., AA, 05: 37, CFJ, p. 69).

${ }^{35}$ HÖLDERLIN, F. Patmos. In: _____ Poemas. Trad. Paulo Quintela. Coimbra: Atlântida, 1959, p. 363.

${ }^{36}$ Cf. LACOUE-LABARTHE, P. A verdade sublime. Trad. Virginia Figueiredo. In : PENNA, João Camillo ; FIGUEIREDO, Virginia (Org.). A imitação dos Modernos. São Paulo: Paz e Terra, 2000, p.226227. Segundo esse autor, Kant se manteve fiel à tradição do sublime que, desde Longino, foi “[...] a apresentação do meta-físico enquanto tal.” Em defesa dessa tese, ele assegura que a expressão kantiana sobre as Idéias Estéticas como “[...] representação da faculdade da imaginação que dá muito a pensar" (KANT, I., AA 05: 193; CFJ, p. 159) nada mais era do que uma transcrição pura e simples de Longino. Assim, divergindo da interpretação de Lyotard, da qual nos apropriamos aqui, a saber: de um primeiro surgimento do sublime como "Retórico" e apenas modernamente transformado em "Filosófico", Lacoue-Labarthe considera que o "sublime dito "do pensamento" nascera já com Longino.

${ }^{37}$ KANT, I. (AA, 05: 97), CFJ, p. 103-104, grifos meus: “O sentimento do sublime é, portanto, um sentimento do despraz̧er a partir da inadequação da faculdade da imaginação, na avaliação estética da grandeza, à avaliação pela razão e, neste caso, ao mesmo tempo um pražer despertado a partir da concordância, precisamente deste juízo da inadequação da máxima faculdade sensível, com idéias racionais, na medida em que o esforço em direção às mesmas é lei para nós.”
} 
O que filósofos como Schiller, Hegel, Heidegger e Adorno chamaram de "Grande Arte" designa a arte capaz de nos conceder a possibilidade daquela experiência, chamemo-la de "perigo e salvação" (Hölderlin), ou, junto com Burke e Kant, de "sublime" (enquanto dor e prazer simultâneos), ou, ainda, com Aristóteles, de "tragédia" (enquanto uma representação que promove a catarse, por sua vez, "terror e piedade purificados"), tanto faz. Porém, atenção! Nesse momento, que coincide, a meu ver, com a condição de possibilidade de um pensamento sublime, a experiência é realizada por um espectador que, ao contrário do sujeito perversamente egoísta, descuida-se, descura-se de si mesmo, desloca-se de si em favor da alteridade (personagem, no caso do teatro), livrando-se até de sua própria subjetividade.

Talvez essa concepção trágica da obra de arte (e estou de acordo com Lacoue-Labarthe, que afirmou ser o Sublime o "nosso" trágico, o "trágico moderno"38 que Hölderlin tanto buscou) tenha como pressuposição necessária a identificação do espectador com a obra, ou de um certo desfalecimento das fronteiras entre o sujeito e o objeto. Aqui, obra de arte não pode ser chamada de objeto, de "Gegenstand", que, em alemão, quer dizer literalmente algo que se antepõe, põe-se contra (um sujeito). Aqui, o objeto absorve o sujeito que se perde, ou, pelo menos, perde temporariamente os limites de sua individualidade rotineira. A experiência do sublime, como diz Jean-Luc Nancy, é uma experiência da "ilimitação", de um ilimitado que age, atua, distendendo os limites estreitos da nossa experiência cotidiana.

Em defesa da nossa concepção trágica da obra de arte, invoquemos a teoria aristotélica da catarse. Ao exigir de maneira algo surpreendente que o herói trágico não seja um homem supremamente bom ${ }^{39}$, parece estar subjacente que o bom funcionamento ou a eficiência da catarse depende da identificação do espectador com o personagem. Como argumentam Rosalyne DupontRoc e Jean Lallot, no seu brilhante comentário à tradução para o francês da Poética: 'Devemos supor então, logicamente, que os 'homens justos' (epieikeis) representam um tipo de perfeição tão elevada que o espectador não pode ver nele um 'semelhante'."' ${ }^{40}$ Os autores lembram ainda que, na Ética a Nicômaco (1137 b 12), "o epieikes era definido como mais justo do que a lei justa, o que

\footnotetext{
${ }^{38}$ LACOUE-LABARTHE, P. Hölderlin e os Gregos. In: A imitação dos modernos, op.cit., p. 217.

${ }^{39}$ ARISTÓTELES. Poética (1452 b 31), op.cit., p. 252.

${ }^{40}$ Cf. Comentário de Rosalyne Dupont-Roc e Jean-Lallot. ARISTÓTELES. La Poétique, Paris: Ed. du Seuil, 1980, p. 241.
} 
verdadeiramente o localizava no cume da excelência ética". Com eles aprendi que 1) o efeito catártico da tragédia: a purificação dos padecimentos - terror, piedade e padecimentos aparentados - que ela provoca no espectador, poderia ser traduzido por outra "alquimia" (a expressão é deles), comum ao século XVIII, e que transforma padecimento/dor em prazer; 2) um ensinamento ainda mais importante, o de que é através da representação (dia mimeseos), ${ }^{41}$ conforme o capítulo 14, da Poética, que se faz essa substituição.

Talvez vocês estejam pensando que aceitar a tese de que a catarse (o efeito trágico por excelência) dependa da identificação do espectador com o herói trágico signifique declarar guerra a uma poderosa (uma vez que é mais atual) inimiga (uma vez que é sua perfeita antípoda), a concepção brechtiana de "distanciamento". Mas isso não é totalmente verdadeiro: 1) porque, se nos for concedido que o sublime seja o trágico moderno, e, portanto, que seja legítimo interpretar o trágico a partir das características modernas do Sublime, então, o trágico também será um sentimento paradoxal. Por isso, na sua proximidade máxima, no momento limite do estado de desproteção, desamparo, o espectador pode, através da representação, tomar sua distância... E reencontrar a noção tão cara a Brecht. No entanto, em segundo lugar, pode-se supor, junto com Heidegger, que a cotidianidade não é autêntica, e que vivemos no preconceito, protegidos pela armadura do teórico, atolados, chafurdados em nós mesmos, na nossa subjetividade rotineira. Nesse último modo de interpretar o processo de identificação do espectador com o personagem, a própria obra comandaria uma espécie de estranbamento, perigosa (mas, rigorosa) comoção, processo que não excluiria nem mesmo certa violência, pois, nos capturaria para um outro tempo e espaço, justamente estranhos à nossa rotina ${ }^{42}$.

O cotidiano costuma nos abrigar, e frequentemente resistimos ao convite ou, às vezes, à intimação que obras de arte nos fazem. Elas nos convocam a habitar o estranho... O Duplo, o Inquietante, onde, talvez se esconda a possibilidade de uma arte (que é o mesmo que o pensamento) sublime. Talvez não haja pensamento autêntico sem um correspondente despojamento da subjetividade. Como dizia, ainda, Heidegger, não sabemos

${ }^{41}$ Cf. Dupont-Roc e Lallot propõem traduzir mimesis por "représentation". Na "Introduction" (p. 1722), eles justificam essa opção inédita e original.

${ }^{42}$ SCHELLING apud LOREAU, M. Poésie et philosophie jumelées à la source. Po\&sie, n 34, p. 75, $3^{\circ}$ trim. de 1985: "Duas saídas apenas permitem escapar da realidade ordinária: a poesia.... e a filosofia". 
de nada, porque ainda não pensamos... Ainda estamos presos à subjetividade, que é uma dessas armaduras, não das mais suaves e flexíveis dentro das quais nos enfiou a tradição filosófica ocidental "protegendo-nos" talvez do que seja uma experiência radical do pensar (onde não apenas se desfazem os limites entre sujeito e objeto, como também as fronteiras entre arte e filosofia).

III.

Nesta última parte, gostaria de apresentar a brilhante análise que fez Lyotard da Investigação filosófica sobre a origem de nossas idéias do sublime e do belo, de Burke, segundo a qual ele considerou a estreita relação do sublime com o tempo como sendo a maior contribuição burkiana. Para acompanhar os detalhes dessa interpretação, faço uma longa citação do ensaio "Le sublime, à présent”, mesmo correndo risco de repetir algumas ideias já explicitadas aqui anteriormente:

O sublime é [um sentimento] suscitado pela ameaça de que nada aconteça. O belo dá um prazer positivo. Mas, há outro tipo de prazer, que está ligado a uma paixão que é mais forte do que a satisfação, que é a dor, e a proximidade da morte. Na dor, o corpo afeta a alma. Mas a alma pode afetar também o corpo como se ele experimentasse uma dor de origem externa, através do único meio de representações associadas inconscientemente a situações dolorosas. Essa paixão, totalmente espiritual, se chama, no léxico de Burke, o terror. Ora, os terrores estão ligados a privações: privação de luz, terror das trevas; privação do outro, terror da solidão; privação de linguagem, terror do silêncio; privação de objetos, terror do vazio; privação de vida, terror da morte. O que aterroriza é que o acontecer não aconteça, [que] pare de acontecer.

Para que esse terror se misture com prazer e componha com ele o sentimento de sublime, é preciso ainda, escreve Burke, que a ameaça que o engendra seja suspensa, mantida à distância, contida. Esse suspense, essa diminuição (amoindrissement) de uma ameaça ou de um perigo provoca uma espécie de prazer que não é certamente uma satisfação positiva, mas, antes, um alívio (soulagement). É ainda uma privação, mas de segundo grau: a alma está privada da ameaça de estar privada de luz, linguagem, vida. Esse prazer de segundo grau: a alma é privada da ameaça de estar privada de luz, linguagem, vida. Esse prazer da privação secundária, Burke o distingue do prazer positivo, e o batiza de delight, délice (deleite).

Eis, então, como se analisa o sentimento sublime: um objeto muito grande, muito poderoso, ameaçando, portanto, privar a alma de todo 'acontecer', a golpeia (frappe) de 'espanto' (a menores graus de intensidade, a alma é tomada de admiração, veneração e respeito). Ela fica estúpida, imobilizada, 
como morta. Ao afastar esta ameaça, a arte promove um prazer de alívio, de deleite. Graças a ele, a alma é devolvida à agitação entre a vida e a morte, e essa agitação é sua saúde e sua vida. O sublime não é mais para Burke questão de elevação (categoria através da qual Aristóteles distinguia a tragédia), mas questão de intensificação. ${ }^{43}$

Embora concorde profundamente com a análise de Lyotard, do sublime burkiano dando ênfase ao tempo, não estou de acordo com sua afirmação de que "a questão do tempo, do Acontecer? não faz parte, pelo menos explicitamente, da problemática de Kant." ${ }^{44}$ Tentarei defender, ao contrário, que, também na "Analítica do Sublime", de Kant, uma das definições importantes do Sublime mantém uma relação com o tempo. No caminho da questão sobre o tempo e a sua estreita relação com a sublimidade, aproveito para tecer, dentre muitos, outro ponto de contato entre Kant e Burke. De um lado, rememoremos que, para Burke, o sentimento do sublime dependia intimamente de uma predisposição nossa, humana, a que ele chamou de "simpatia", capacidade de experimentar a dor alheia, de nos colocarmos no lugar de outro:

"Pois a simpatia deve ser considerada uma espécie de substituição, mediante a qual nos colocamos no lugar de outrem, e somos afetados, sob muitos aspectos, da mesma maneira que eles". ${ }^{45}$

De outro lado, lembremos a máxima da faculdade do juízo, à qual Kant chamou de "maneira de pensar alargada", e que consiste em "pensar no lugar de qualquer outro". ${ }^{46}$ Vejamos como essa máxima kantiana está próxima da "simpatia" de Burke:

"Aqui não se trata da faculdade de conhecimento, mas da maneira de pensar, para fazer dela um uso conveniente [...]; a qual, por menor que também seja o âmbito e o grau que o dom natural do homem atinja, mesmo assim denota uma pessoa com maneira de pensar alargada, quando ela não se importa com as condições privadas subjetivas do juízo, dentro das quais tantos outros estão como que entalados, e reflete sobre o seu juízo desde um ponto de vista

\footnotetext{
${ }^{43}$ LYOTARD, J.F. Le sublime, à présent, op.cit., p. 104. Ver também nota 7.

44 Ibid.

45 BURKE, E., op. cit., p. 52.

${ }^{46}$ KANT, I. (AA, 05: 158); CFJ, p. 140-141. Kant descreve, na verdade, três máximas. Além daquela da faculdade do juízo, há o "pensar por si", que rege o entendimento livre de preconceitos; e o "pensar de acordo consigo mesmo" ou "pensar conseqüente", que é uma regra da razão. 
universal (que ele somente pode determinar enquanto se imagina no ponto de vista dos outros)." ${ }^{.47}$

Desculpem-me o agravamento do "desvio", mas é inevitável aqui convocar Heidegger, e junto com ele valorizar essa nossa capacidade de transporte, de nos movimentarmos em direção ao que está fora de nós. Poderíamos ser, nós, seres humanos, estruturas absolutamente perfeitas, contudo, impenetráveis, indiferentes ao que se passa à nossa volta. Sem dúvida, são nossas formas a priori da sensibilidade, o tempo e o espaço, que garantem essa possibilidade à nossa subjetividade. Como vimos, Kant promoveu uma verdadeira "revolução copernicana" para a Estética, quando, pela primeira vez na história da filosofia, transformou o tempo e o espaço, que eram ainda "categorias", segundo o quadro das funções lógicas do juízo aristotélico, ainda em vigor no século XVIII, em intuicões puras produzidas pela sensibilidade, dignificando, desse modo, essa faculdade ao atribuir-lhe o nobre adjetivo de "transcendental". Talvez, os resultados dessa "Revolução" ainda não tenham sido, até hoje, mais de duzentos anos depois de sua primeira publicação, totalmente absorvidos.

Promovidas ao nível "transcendental", faculdades como a sensibilidade e a imaginação não podem mais ser desprezadas como costumavam ser pelo nosso modo tradicional de pensar, da preconceituosa metafísica, que sempre pensou nelas como "falhas", "imperfeições", já que o modelo da racionalidade era o divino. Apenas na modernidade, a finitude passa a ser a nossa "perfeição" e "qualidade", e a sensibilidade deixa de ser a faculdade que nos "animaliza", igualando-nos aos demais seres vivos, vegetal ou animal, mas agora positivamente, o que nos distingue do Deus que, sendo pura razão ou vontade, é insensível. A vontade racional, faculdade que compartilhamos com Deus, é tão infinita Nele quanto em nós. Entretanto, desde a Primeira Crítica, pelo menos, a nossa razão teórica foi obrigada a tornar-se ateia e a finitude apareceu como seu limite, bemvindo, aliás, como nos diria mais uma vez o poeta Hölderlin: "pois a infidelidade divina é o que há de melhor para lembrar". ${ }^{48}$

Embora não pretenda de modo algum seguir aqui todo o caminho muito complexo e longo da "Teoria da Imaginação", em Kant, cabe mencionar que, já na $1^{a}$ Crítica, havia uma espécie de "Teoria da Imaginação",

${ }^{47}$ KANT, I. (AA, 05: 159); CFJ, p. 141. Tradução ligeiramente modificada.

${ }^{48}$ HÖLDERLIN, F. Observações sobre o Édipo. In: MACHADO, Roberto (Org.). Hölderlin \& Beaufret Trad. Pedro Süssekind. Rio de Janeiro: Jorge Zahar, 2008, p. 79. 
a qual, segundo Heidegger ${ }^{49}$, a $3^{\text {a }}$ Crítica vem somente completar, uma vez que ela fora amputada pelas concessões feitas por Kant, na publicação da $2^{\mathrm{a}}$ edição da Primeira Crítica. No âmbito da $3^{\mathrm{a}}$ Crítica, a imaginação aparece não apenas como "a faculdade da síntese", mas também, somadas a ela (ou talvez, especificando a síntese), duas outras funções: a primeira, a da apreensão, comandada por si mesma, quer dizer, sem os limites impostos pelos conceitos do entendimento, a imaginação está liberada para avançar perigosamente em direção ao Indeterminado, podendo mesmo redefinir os limites de cada coisa, sem problema. É a chamada síntese da apreensão, cujo sentido progressivo não impõe limites.

Já na síntese da "compreensão", que é a segunda função da imaginação, na $3^{\text {a }}$ Crítica [substituindo expressivamente, a meu ver, a síntese empírica e "reprodutiva" da $1^{a}$ Crítica, há um limite interno, estabelecido pela própria imaginação, e, na medida em que se dá a própria lei de constituição, a faculdade ascende ou é promovida ao âmbito do transcendental; e esse] limite (há um) que impede a imaginação de progredir infinitamente em suas apreensões sucessivas; que obriga a imaginação, a cada nova apreensão, regredir e sintetizar o já apreendido; que constitui a memória; esse limite, poderíamos chamá-lo simplesmente "tempo". Como todos vocês sabem, em Kant, o tempo é designado "sentido interno" (enquanto o espaço, "sentido externo"). Voltando à minha pequena objeção a Lyotard, mostro uma das importantes (pelo menos, a meu ver) acepções do sublime na $3^{a}$ Crítica: que ele é "um movimento subjetivo da imaginação, pelo qual ela violenta $a^{50}$ o sentido interno, violência que deve ser tanto mais perceptível quanto maior for o quantum que a imaginação compreende numa intuição". ${ }^{1}$

Ora, é essa função de compreensão que, não conseguindo realizar a síntese, diante do dado muito grande do sensível, leva a imaginação a violentar o sentido "natural"- Kant diria "empírico"- do tempo se dar a nós, ou seja, seu modo sucessivo. Esse modo sucessivo e rotineiro da subjetividade estar no mundo é o que a assegura que, depois de cada noite, haverá uma aurora, um novo dia e tantas outras crenças que a abrigam e a deixam adormecer

\footnotetext{
${ }^{49}$ HEIDEGGER, M. Kant et le problème de la métaphysique. Trad. A. de Waelhens e W. Biemel. Paris: Gallimard, 1981, p. 218.

${ }^{50}$ Minha análise tem uma profunda afinidade com a de Jacob Rogozinski, e concorda com a sua queixa... (Le Don du monde. In: Du Sublime, op.cit., p. 189:) "Talvez não se tenha prestado atenção suficiente a um termo que retorna muitas vezes no texto de Kant : o da violência."

${ }^{51}$ KANT, I. (AA, 05: 100), CFJ, p. 105. 
tranquila. A função da síntese compreensiva, não conseguindo realizarse, impõe uma interrupção na cadeia sucessiva, que é experimentada como ameaça, e, pior, como a mais terrível de todas, ou, como dizia Lyotard, junto com Burke, o tempo pára e ameaça não prosseguir, não continuar nem retomar a cadeia sucessiva... Em termos de vivência psicológica e emocional... É a morte! (Aqui, estamos em Burke).

Escrevendo sobre a obra de Barnett Baruch Newman ${ }^{52}$, especialmente sobre dois quadros cujo título era Now (Jetət, ou Nun), Lyotard se serve, não por acaso, do conceito heideggeriano de "Ereignis", para tentar descrever esse "Acontecer", cuja dimensão invariavelmente escapa da nossa consciência, que consegue pensar no quid (etwas, o quê), no "que algo aconteça", mas não no quod, que quer dizer (mais simplesmente) "que aconteça", antes mesmo de ser algo... Também eu tentei capturar muito mais timidamente, claro, esse instante, que é vazio, pura interrupção, suspensão, o qual, talvez, devesse ter chamado de "transcendental" ("instante transcendental"), todavia, há vinte anos, denominei-o "experiência do espaço e tempo absolutos" não subscrevo mais, cuja inspiração é bem possível que tenha encontrado na seguinte passagem (momento da qualidade) da "Analítica do Sublime" de Kant (e não em Burke, ainda pensando na objeção a Lyotard), com a qual termino este texto. Sem intenção de comentar esse trecho difícil e até, aparentemente, truncado, e chamando atenção somente para o fato de Kant associar os movimentos da imaginação (apreensão e compreensão) com as intuições da sensibilidade, espaço e tempo respectivamente, deixo-o livre para a imaginação do leitor interpretar:

Medição de um espaço (como apreensão) é ao mesmo tempo descrição do mesmo, por conseguinte movimento objetivo na imaginação (Einbildung) e um progresso; a compreensão da pluralidade na unidade, não do pensamento mas da intuição, por conseguinte do sucessivamente apreendido em um instante, é contrariamente um regresso, que de novo anula a condição temporal no progresso da faculdade da imaginação e torna intuível a simultaneidade. Ela é, pois (já que a sucessão temporal é uma

\footnotetext{
${ }^{52} \mathrm{O}$ ensaio de Lyotard, tão compulsado aqui, "Le sublime, à présent", reunia dois textos sobre Newman: o primeiro, de 1982, publicado na revista norte-americana Artforum, e o segundo, do final de 1983, talvez um catálogo de exposição realizada no Museu de Belas Artes de Bruxelas. Se compartilho plenamente, como já exprimi, da interpretação do sublime em Burke, presente nos dois textos citados, o mesmo não posso dizer, infelizmente, quanto às especulações exageradas (a respeito das relações entre arte, vanguarda, economia capitalista, mercado, metafísica etc.), através das quais Lyotard encerra o seu texto.

${ }^{53}$ Ver nota 27.
} 
condição do sentido interno e de uma intuição), um movimento subjetivo da faculdade da imaginação, pelo qual ela faz violência ao sentido interno, a qual é tanto mais perceptível quanto maior é o quantum que a faculdade da imaginação compreende em uma intuição. O esforço, portanto, de acolher em uma única intuição uma medida para grandezas, cuja apreensão requer um tempo considerável, é um modo de representação que, considerado subjetivamente, é contrário a fins, objetivamente, porém, é necessário à avaliação da grandeza, por conseguinte conforme a fins: no que contudo a mesma violência que é feita ao sujeito através da faculdade da imaginação é ajuizada como conforme a fins com respeito à destinação inteira do ânimo.

A qualidade do sentimento sublime consiste em que ela é, relativamente à faculdade de ajuizamento estética, um sentimento de desprazer em um objeto, contudo representado ao mesmo tempo conforme a fins; o que é possível pelo fato de que a incapacidade (Unvermögen) própria descobre a consciência de uma faculdade (Vermögen) ilimitada do mesmo sujeito, e que o ânimo só pode ajuizar esteticamente a última através da primeira. ${ }^{54}$

FIGUEIREDO, Virginia. O Sublime explicado às crianças.Trans/Form/Ação, (Marília); v.34, p.35-58, 2011, Edição Especial 2.

ABSTRACT: As indicated by its title, the aim of this essay is debating with the contemporary French philosophy reception of Kant's concept of the sublime, particularly with Jean-François Lyotard. As a consequence of this French influence, instead of highlighting, as traditional commentators tend to do, the moral and systematic implications of Kantian sublime, this essay takes Kant's notion as intended in the first place to account for an essential aspect of our experience of art. But, at the same time, I want to distance myself from Lyotard's interpretation and object to his view that Burke's notion of the sublime is more adequate than Kant's conception for understanding contemporary art. In particular, I want to hold that it is possible to understand time (that Lyotard takes to be the central aspect of Burke's notion) as being also a key feature of Kantian sublime.

KEYWORDS: Kant. Jean-François Lyotard. Aesthetics. Sublime.

\section{REFERÊNCIAS}

ARISTÓTELES. A Poética. Trad. Eudoro de Souza. Rio de Janeiro: Ed. Abril Cultural, 1979 (Col. Os pensadores). ARISTOTE, La Poétique. Trad. Rosalyne Dupont-Roc e Jean-Lallot, Paris: Ed. du Seuil, 1980.

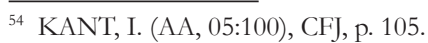


BURKE, E. Uma investigação filosófica sobre a origem das nossas idéias do sublime e do belo. Trad. Enid Abreu Dobránszky. Campinas, SP: Papirus; Editora da Universidade de Campinas, 1993. BURKE, E. Recherche philosophique sur l'origine de nos idées du sublime et du beau. Trad. E. Lagentie de Lavaisse. Paris: Librarie Philosophique J. Vrin, 1973.

CROWTHER, Paul. The kantian sublime, Oxford: Oxford University Press, 1989.

ESCOUBAS, E. Kant ou la simplicité du sublime. In: DEGUY, M.; NANCY, J. L. (Org.). Du Sublime. Paris: Belin, 1988.

HEIDEGGER, M. Kant et le problème de la métaphysique. Trad. A. de Waelhens e W. Biemel, Paris: Gallimard, 1981.

HÖLDERLIN, F, Poemas. Trad. Paulo Quintela. Coimbra: Atlântida, 1959.

. Observações sobre o Édipo. In: MACHADO, Roberto (Org.).Hölderlin \& Beaufret. Trad. Pedro Süssekind. Rio de Janeiro: Jorge Zahar, 2008.

KANT, I. Crítica da Faculdade do Juízo. Trad. Valério Rohden e Antonio Marques, Rio de Janeiro: Forense Universitária, 1993.

LACAN, J. O Seminário - livro VII, A Ética da psicanálise. Rio de Janeiro: Zahar, 1988.

LACOUE-LABARTHE, P. A imitação dos Modernos. orgs. J. C. Penna e V. Figueiredo. São Paulo: Paz e Terra, 2000.

LOREAU, M. Poésie et philosophie jumelées à la source. Po\&sie, no $34,3^{\circ}$ trim. de 1985.

LYOTARD, J. F. Le sublime, à présent. Po\&sie, no 34, Paris, $3^{\circ}$ trimestre, 1985.

- Lições sobre a Analitica do sublime. Trad. Constança Marcondes César e Lucy R. Moreira César. Campinas, SP: Papirus, 1993.

NANCY, J. L. L'offrande sublime. In: DEGUY, M.; NANCY, J. L. (Org.). Du Sublime. Paris: Belin, 1988.

ROGOZINSKI, J. Le don du monde. In: DEGUY, M. ; NANCY, J. L. (Org.). Du Sublime. Paris: Belin, 1988.

SCHILLER, F. A educação estética do homem numa série de cartas. Trad. de Roberto Schwarz e Márcio Suzuki. São Paulo: Iluminuras, 1990. 